Zsuzsanna Zsibók

\title{
Extrapolative techniques' predictive capacity in the spatial downscaling of the Hungarian gross domestic product*
}

\author{
ZSUZSANNA ZSIBÓK \\ Research Fellow \\ Centre for Economic and Regional Studies, \\ Hungary \\ Email: zsibok.zsuzsanna@krtk.mta.hu
}

The dynamics of GDP (gross domestic product) and its spatial distribution are constantly at the forefront of economic and regional studies. This study intends to understand better Hungarian subnational economic processes by checking the predictive capacity of various extrapolative forecasting techniques with out-of-sample testing. The author focuses on a top-down projection method that allocates regional GDP based on an existing, external, national-level, long-term projection. GDP is analysed in its aggregate value and in a decomposition followed in the growth accounting literature. The main question of the out-of-sample tests is the level of usefulness of historical national- and regional-level data in predicting Hungarian regional-level GDP in the long run. The author proposes a specific weighting scheme that combines past regional-level growth rates and predicted national-level growth rates to arrive at different regional-level predictions. She concludes that during the relatively short test period, the average historical inter-regional distribution did not have a determining role in predicting future regional GDP values. The nationallevel growth processes largely explain regional-level GDP, and the use of certain combinations of past regional-level growth rates and predicted national-level growth rates are recommended to project regional GDP in the long run.

KEYWORDS: extrapolative projection, spatial downscaling, accuracy measures

Scrutiny of the quantitative foresight of dynamics of regional economic inequalities appear periodically from public bodies and regional scholars, since the long-term dynamics of spatial concentration or spatial re-balancing may have

* This study has been made within the framework of Project No. 120004 with support from the National Research, Development and Innovation Fund of Hungary, financed under the K16 funding scheme.

Hungarian STATISTICAL REVIEW, VOLUME 2, NuMBER 2, PP. 51-78. DOI: 10.35618/hsr2019.02.en051 
significant consequences regarding the conditions experienced by people living in different regions (Royuela-Veneri-Ramos [2019]). This is also the case in Hungary (Czirfusz-Hoyk-Suvák [2015]). The most important indicator of regional economic development remains the GDP (or gross value added) despite admitted problems with the indicator per se (Stiglitz-Sen-Fitoussi [2010]) and its regional estimation (DusekKiss [2008]). It may be assumed that national growth level is not sufficiently representative of regional growth processes for sub-national units, excepting the largest ones. Regardless, past regional growth rates do not always transfer the best input to predict future sub-national growth. In this study, we argue that some combination of past regional-level and projected national-level growth rates may deliver proper information for our extrapolations. Guidance on these long-term projections are provided by theories and historical distributional data (Jakobi [2004]). This study focuses more on the latter by examining the accuracy of certain simple and transparent extrapolative methods in projecting economic growth at the regional level.

To our knowledge, long-term economic (GDP) projections are not available for Hungary at the sub-national level in recent literature. Similar ex-ante modelling intentions flourished approximately 30 to 50 years ago ( $L u x$ [2015]). However, recent ex-ante models are elaborated at the national level as either short-run macroeconometric models (Balatoni-Mellár [2011]) or long-run macro models (ECO-TREND model by Keresztély [2004]), or they focus on forecasting demographic and labour market processes (see Baranyai [2015]). Hungarian subnational models are primarily prepared with the aim of impact assessment (Varga [2018]) or short-term input-output analysis (Smahó [2007]). Jakobi [2004] forecasted the dynamics of the main indicators of territorial inequalities in Hungary in an analytical trend approach and predicted widening spatial disparities respecting some selected economic indicators.

This study aims to investigate the combinations of past regional-level growth rates and projected national-level growth rates that are most effective to predict future regional-level growth in a spatial downscaling approach. Section 1 introduces the database and the methodology, followed by the results in Section 2, and finally, the conclusions in Section 3.

\section{Data and methodology}

This section takes a look on the sources and the results of the available nationallevel projections and the methodological background of their regional downscaling, as well as the accuracy tests.

Hungarian Statistical ReVIEW, Volume 2, NumBER 2, PP. 51-78. DOI: 10.35618/hsr2019.02.en051 


\subsection{National-level projections and some simple regionalisation approaches}

This paper aims to project the long-term dynamics of the GDP in Hungary at county level by downscaling an exogenous national-level projection, and subsequently check the predictive capacity of the projections. Two data sources are used in this exercise: national-level projections and county-level historical data. National-level projections are obtained from an external source, namely, 'The 2015 Ageing Report' published by the European Commission (EC [2015]). The main reasons for choosing this projection is that the results and the documentation of the underlying methodology are readily available, and the results fall in the middle range of other relevant projections (such as Riahi et al. [2017], OECD [2019]). Regarding national-level GDP projections, a production function framework is used in which demographic projections and assumptions for the labour force have a profound impact on economic growth (see $E C$ [2015] pp. 77-78.):

$$
Y=T F P \cdot L^{\beta} \cdot K^{1-\beta},
$$

where $Y$ is total output (GDP), $L$ is the labour supply (number of workers), $K$ is the stock of capital, TFP is the total factor productivity ${ }^{1}, \beta$ is the labour share, and the share of labour costs in total value added is conventionally set at 0.65 . In this framework, labour productivity (GDP per worker) is driven by total factor productivity and the capital stock per worker:

$$
\frac{Y}{L}=T F P \cdot\left(\frac{K}{L}\right)^{1-\beta}
$$

At the national level, the projection takes into account the catching-up potential of those countries where per capita GDP is lower than the EU average, including Hungary. The long-run TFP growth rate is assumed $1 \%$ per annum for all EU countries. This implies that in countries that are 'catching-up', the TFP growth rate gradually converges towards $1 \%$ throughout the projection horizon, while countries with a relatively better income position are assumed to reach this rate by 2035. (See $E C[2015]$ p. 82.)

\footnotetext{
${ }^{1}$ TFP represents the growth of total output that is not explained by the growth of labour and capital inputs (TFP accounts for the effects of, for example, technological development or institutional factors).
}

HungaRian STATISTICAL REVIEW, Volume 2, NuMBER 2, PP. 51-78. DOI: 10.35618/hsr2019.02.en051 
Projections of selected national-level economic indicators for Hungary

\begin{tabular}{|c|c|c|c|c|c|c|c|c|c|}
\hline Indicator & 2020 & 2025 & 2030 & 2035 & 2040 & 2045 & 2050 & 2055 & 2060 \\
\hline $\begin{array}{l}\text { Potential GDP (growth } \\
\text { rate; } \% \text { ) }\end{array}$ & 1.94 & 2.14 & 1.99 & 1.50 & 1.18 & 1.32 & 1.38 & 1.15 & 1.00 \\
\hline $\begin{array}{l}\text { Potential GDP per } \\
\text { worker (growth rate; } \\
\% \text { ) }\end{array}$ & 1.44 & 2.10 & 2.20 & 2.08 & 2.08 & 2.08 & 1.90 & 1.73 & 1.55 \\
\hline Population (thousands) & $9,795.02$ & $9,739.63$ & $9,671.68$ & $9,594.06$ & $9,513.28$ & $9,433.20$ & $9,340.88$ & $9,250.93$ & $9,154.45$ \\
\hline $\begin{array}{l}\text { Working age } \\
\text { population } \\
\text { (age group 15-64; \% } \\
\text { of total population) }\end{array}$ & 65.31 & 64.14 & 63.70 & 62.71 & 61.06 & 58.90 & 58.09 & 57.19 & 56.10 \\
\hline $\begin{array}{l}\text { Employment rate (age } \\
\text { group } 15-64 ; \%)\end{array}$ & 65.71 & 68.18 & 68.56 & 68.31 & 67.82 & 67.82 & 67.81 & 67.62 & 67.52 \\
\hline
\end{tabular}

Note. Here and hereinafter, GDP: gross domestic product.

Source: EC [2015].

The spatial downscaling of national-level projections will be elaborated with the help of historical time series available from the HCSO (Hungarian Central Statistical Office) and the TeIR (National Regional Development and Spatial Planning Information System). We compute GDP at constant, 2005 prices with the help of the GDP deflator published by MNB (hereinafter NBH [the National Bank of Hungary]). Comparable NUTS-3-level data are available from 2000 to 2018 (to 2017 for GDP and productivity). We opt to use the NUTS 3 level in our analysis since it is the lowest territorial level for which GDP estimations are released, and the NUTS-3level resolution better reflects the actual spatial structure of the economy than the NUTS 2 level (Lengyel-Kotosz [2018]). (See Table 2.)

Several methodological options are available to elaborate the spatial downscaling of national aggregate data ${ }^{2} .1$. The simplest approach assumes that the average past cross-sectional distribution of economic performance will follow throughout the projection horizon (e.g. Gaffin et al. [2004]) or, alternatively, the allocation of the aggregate GDP between the regions is determined by some composite indicator: a Hungarian top-down example (without an ex-ante analysis) is presented by Koppány-Kovács-Dusek [2019] who disaggregate the estimated gross value added to the settlement level. 2. The convergence assumption applies convergence functions of specific (linear or non-linear) forms that establish a functional relationship between the initial development position of a sub-national territorial unit and its projected growth rate. 3. A factor model harnesses the link between regional

${ }^{2}$ For more detailed examples of selected methodologies beyond those mentioned here, see Zsibók [2018]. 
and national economic growth. This approach assumes an approximate factor model structure for country-level variables, where the common component includes national GDP growth as the common factor and a region's exposure to national GDP growth (Rapach-Strauss [2012], Kopoin-Moran-Paré [2013]).

Our methodological choice combines past regional-level growth rates and projected national-level growth rates to arrive at the projected regional-level growth trajectories in an extrapolative manner.

Table 2

\begin{tabular}{|c|c|c|c|c|c|c|c|c|c|c|}
\hline \multirow{3}{*}{ NUTS 3 region/Country } & \multicolumn{2}{|c|}{$\begin{array}{c}\text { Population } \\
\text { (2000-2018) }\end{array}$} & \multicolumn{2}{|c|}{$\begin{array}{l}\text { Productivity } \\
(2000-2017)\end{array}$} & \multicolumn{2}{|c|}{$\begin{array}{l}\text { Working-age } \\
\text { population } \\
(2000-2018)\end{array}$} & \multicolumn{2}{|c|}{$\begin{array}{l}\text { Employment } \\
\text { (2000-2018) }\end{array}$} & \multicolumn{2}{|c|}{$\begin{array}{c}\text { GDP } \\
(2000-2017)\end{array}$} \\
\hline & $\begin{array}{l}\text { Re- } \\
\text { gional } \\
\text { shares }\end{array}$ & $\begin{array}{l}\text { Re- } \\
\text { gional } \\
\text { growth } \\
\text { rates }\end{array}$ & $\begin{array}{c}\text { National } \\
\text { value }= \\
100 \%\end{array}$ & $\begin{array}{l}\text { Re- } \\
\text { gional } \\
\text { growth } \\
\text { rates }\end{array}$ & $\begin{array}{l}\text { Re- } \\
\text { gional } \\
\text { shares }\end{array}$ & $\begin{array}{l}\text { Re- } \\
\text { gional } \\
\text { growth } \\
\text { rates }\end{array}$ & $\begin{array}{l}\text { Re- } \\
\text { gional } \\
\text { shares }\end{array}$ & $\begin{array}{l}\text { Re- } \\
\text { gional } \\
\text { growth } \\
\text { rates }\end{array}$ & $\begin{array}{l}\text { Re- } \\
\text { gional } \\
\text { shares }\end{array}$ & $\begin{array}{l}\text { Re- } \\
\text { gional } \\
\text { growth } \\
\text { rates }\end{array}$ \\
\hline & \multicolumn{10}{|c|}{$\%$} \\
\hline Budapest & 17.33 & -0.03 & 191,89 & 1.77 & 17.40 & -0.28 & 19.10 & 0.63 & 36.69 & 2.51 \\
\hline Pest & 11.80 & 0.97 & 80,34 & 1.89 & 11.86 & 0.73 & 12.50 & 1.84 & 10.01 & 3.71 \\
\hline Fejér & 4.25 & -0.16 & 91,40 & 0.86 & 4.30 & -0.33 & 4.50 & 0.89 & 4.12 & 1.72 \\
\hline Komárom-Esztergom & 3.09 & -0.37 & 93,32 & 2.64 & 3.13 & -0.57 & 3.34 & 0.73 & 3.12 & 3.41 \\
\hline Veszprém & 3.59 & -0.56 & 70,65 & 0.83 & 3.62 & -0.79 & 3.79 & 0.18 & 2.69 & 1.15 \\
\hline Győr-Moson-Sopron & 4.45 & 0.36 & 108,46 & 1.77 & 4.53 & 0.20 & 4.91 & 1.21 & 5.32 & 2.88 \\
\hline Vas & 2.61 & -0.36 & 85,75 & 1.30 & 2.63 & -0.47 & 2.89 & 0.25 & 2.48 & 1.36 \\
\hline Zala & 2.88 & -0.61 & 77,03 & 1.35 & 2.89 & -0.82 & 3.09 & 0.02 & 2.39 & 1.24 \\
\hline Baranya & 3.89 & -0.67 & 74,91 & 0.61 & 3.91 & -0.90 & 3.60 & 0.54 & 2.70 & 0.87 \\
\hline Somogy & 3.23 & -0.62 & 71,13 & 1.48 & 3.21 & -0.79 & 2.92 & -0.04 & 2.09 & 1.40 \\
\hline Tolna & 2.36 & -0.80 & 75,58 & 1.00 & 2.36 & -0.96 & 2.29 & 0.16 & 1.74 & 0.94 \\
\hline Borsod-Abaúj-Zemplén & 7.03 & -0.88 & 76,03 & 1.58 & 6.91 & -0.93 & 6.02 & 0.86 & 4.57 & 2.46 \\
\hline Heves & 3.13 & -0.60 & 75,84 & 1.61 & 3.08 & -0.77 & 2.91 & 0.40 & 2.21 & 1.82 \\
\hline Nógrád & 2.07 & -0.87 & 53,55 & -0.10 & 2.04 & -1.02 & 1.86 & 0.57 & 1.00 & 0.06 \\
\hline Hajdú-Bihar & 5.43 & -0.25 & 80,22 & 0.89 & 5.45 & -0.29 & 4.99 & 1.18 & 3.99 & 2.01 \\
\hline Jász-Nagykun-Szolnok & 3.96 & -0.73 & 68,79 & 1.26 & 3.90 & -0.83 & 3.74 & 0.49 & 2.58 & 1.61 \\
\hline Szabolcs-Szatmár-Bereg & 5.71 & -0.32 & 65,27 & -0.20 & 5.70 & -0.18 & 4.91 & 1.98 & 3.17 & 1.86 \\
\hline Bács-Kiskun & 5.28 & -0.47 & 72,06 & 1.81 & 5.24 & -0.59 & 5.16 & 0.63 & 3.72 & 2.43 \\
\hline Békés & 3.72 & -1.01 & 66,38 & 0.19 & 3.66 & -1.10 & 3.38 & 0.52 & 2.25 & 0.63 \\
\hline Csongrád & 4.18 & -0.43 & 77,25 & 1.01 & 4.18 & -0.61 & 4.10 & 0.41 & 3.17 & 1.33 \\
\hline Hungary & 100.00 & -0.25 & 100.00 & 1.38 & 100.00 & -0.40 & 100.00 & 0.80 & 100.00 & 2.18 \\
\hline
\end{tabular}

Note. Deviations from 100.00 result from rounding.

Source: HCSO, TeIR and NBH data.

Hungarian Statistical REVIEW, VOluME 2, NuMBER 2, PP. 51-78. DOI: 10.35618/hsr2019.02.en051 


\subsection{The decomposition of per capita GDP}

In this study, GDP is predicted in two ways: we apply the trend approach (see later) on the aggregate GDP series and on factors of the decomposed GDP. These components are computed from the following decomposition of the per capita GDP (Szabó [2015], Lengyel-Varga [2018]):

$$
\frac{G D P}{\text { population }}=\frac{G D P}{\text { employed persons }} \cdot \frac{\text { employed persons }}{\text { working age population }} \cdot \frac{\text { working age population }}{\text { population }},
$$

that is,

per capita GDP = labour productivity $\cdot$ employment rate $\cdot$ the share of working age population, /4/

from which we get the GDP as

$G D P=$ population $\cdot$ labour productivity $\cdot$ employment rate $\cdot$ the share of working age population $. / 5 /$

Lengyel [2000] analysed these components as elements by which regional competitiveness can be measured and emphasised that this approach expresses the interdependent relation between regional income, labour productivity, and employment. This approach highlights the importance of the human factors: two elements of this relationship are directly linked to demographic processes (population and the share of working age population), employment rate is linked to the social environment, whereas labour productivity is the factor that is most related to economic circumstances.

\subsection{Trend approach: three (and many more) variants}

The method of the regionalisation procedure in this study is adopted from Batista e Silva et al. [2016], who regionalised national-level European economic and demographic projections according to two scenarios. First, their 'trend' scenario assumes that past regional and sectoral growth rates will continue in the future, however, they are not constant in time, but converge towards the national growth rate and follow it after 2035. Second, their 'convergence' scenario assumes that the regional economic growth rates are driven by a beta convergence relationship established between the initial level of per capita GDP and productivity, and their annual growth rates through the time horizon of their database (1995 to 2013). Based

HungaRian STATISTICAL REVIEW, Volume 2, NuMBER 2, PP. 51-78. DOI: 10.35618/hsr2019.02.en051 
on their work, it is useful to apply a proportional ex-post rescaling which ensures that the sum of the projected regional GDP volumes equals the national-level projected GDP aggregate. Without this ex-post rescaling, the top-down nature of our projections would be given up. The following equation delivers the rescaled NUTS3-level values:

$$
Y_{i, t+n}=Y_{H U, t+n} \cdot \frac{Y_{i, t+n}^{\prime}}{\sum_{i=1}^{r} Y_{i, t+n}^{\prime}},
$$

where $Y_{i, t+n}$ is the projected GDP of the $i^{\text {th }}$ region after rescaling in period $t+n$, $Y_{H U, t+n}$ is the projected national GDP in period $t+n, Y_{i, t+n}^{\prime}$ is region $i$ 's projected GDP in period $t+n$ before rescaling, $\sum_{i=1}^{r} Y_{i, t+n}^{\prime}$ is the sum of regional GDP values in period $t+n$ before rescaling, $r=20$ is the number of regions, $t=2017$ is the base year, and $n$, running from 1 to 43 , is the number of years in the projection horizon (from 2018 to 2060).

In the present study, we adapt the trend assumption of Batista e Silva et al. [2016] with a slight modification. The variants of trend extrapolations compute the projected regional-level growth rates as a combination of past regional-level growth rates and projected national-level growth rates, and they are elaborated according to the following equation:

$$
g_{i, t+n}^{Y}=w_{H U, t+n} \cdot g_{H U, t+n}^{Y}+w_{r e g, t+n} \cdot g_{i, t B}^{Y},
$$

where superscript $Y$ denotes GDP, hence, $g_{i, t+n}^{Y}$ is the growth rate of GDP in region $i(i=1$ to 20$)$ in period $t+n, g_{i, t B}^{Y}$ is the average past growth rate in the base period $\left(t_{B}=2000\right.$ to 2017), $g_{H U, t+n}^{Y}$ is the projected national level GDP growth rate in period $t+n, w_{H U, t+n}$ and $w_{\text {reg,t+n}}$ are the time-varying weights assigned to the projected national growth rate and the past regional average growth rate in period $t+n$, respectively, with $w_{\text {reg, } t+n}=1-w_{H U, t+n}$. (See Table 3.) We start our extrapolations from the year 2018 on a yearly interval. For practical purposes, we transformed the national projections from a 5-year interval to a yearly interval with cubic spline interpolation (Rappai [2014]). 
The weighting system for computing future regional growth rates - three basic cases

\begin{tabular}{c|c|c|c|c|c|c}
\hline \multirow{2}{*}{$\begin{array}{c}\text { Projection } \\
\text { period }\end{array}$} & \multicolumn{2}{|c|}{ Variant 1 } & \multicolumn{2}{c|}{ Variant 2 } & \multicolumn{2}{c}{ Variant 3 } \\
\cline { 2 - 7 } & $w_{H U}$ & $w_{\text {reg }}$ & $w_{H U}$ & $w_{\text {reg }}$ & $w_{H U}$ & $w_{\text {reg }}$ \\
\hline $2018-2024$ & 1.0 & 0.0 & 0.0 & 1.0 & 0.0 & 1.0 \\
\hline $2025-2029$ & 1.0 & 0.0 & 0.0 & 1.0 & 0.2 & 0.8 \\
\hline $2030-2034$ & 1.0 & 0.0 & 0.0 & 1.0 & 0.4 & 0.6 \\
\hline $2035-2039$ & 1.0 & 0.0 & 0.0 & 1.0 & 0.6 & 0.4 \\
\hline $2040-2044$ & 1.0 & 0.0 & 0.0 & 1.0 & 0.8 & 0.2 \\
\hline $2045-2060$ & 1.0 & 0.0 & 0.0 & 1.0 & 1.0 & 0.0 \\
\hline
\end{tabular}

According to Variant 1, the future regional-level growth rate is estimated with the projected national-level growth rate, which could be equivalent to the assumption that the average past cross-sectional distribution of regional GDP remains constant over the projection horizon. However, if we compute the results with this weighting scheme, it will freeze the cross-sectional distribution at the level measured in the initial year (in 2017). In order to reflect the average historical regional shares within national aggregates, values of the initial period should be recalculated accordingly. In this variant, no convergence or divergence occurs between the regions, therefore, it could be a 'benchmark' projection. Variant 2 uses only the average past regional growth rates to project future regional growth, hence, rising regional inequalities are expected throughout the projection horizon. (See Figure 2.) Variant 3 combines the first two options and assumes that, at the first part of the projection horizon, past regional growth rates determine future regional growth prospects, though with decreasing weight. That is, they gradually converge towards the projected national growth rate. Later on, the national-level projected growth rate gains increasing importance in determining growth, because it might be more accurate to estimate regional-level economic processes with the national-level growth rate due to uncertainty of the distant future.

The advantage of the weighting system of Equation /7/ is that the weights are flexibly adjustable including, for example, equal, time-invariant weights (e.g. $w_{H U, t+n}=w_{\text {reg }, t+n}=0.5$ ) or time-varying weights that set the convergence period (the period in which the projected regional and the national growth rates become equal, that is, $\left.w_{H U, t+n}=1\right)$ to an earlier or a later date. This approach reflects the assumption that, to a certain degree, national economic developments spill over into regional-level growth processes; however, the complementing part of the effects is retained to express regional specificities. This assumption is similar to 
an aforementioned factor model. Variants 1 and 2 represent the lower and the upper limit of the projections regarding the cross-sectional variation of regional-level GDP values, and all other variants fall between these 'extremes'.

The different methods may reflect our assumptions regarding the future evolution of regional inequalities, which means that they could represent different spatial scenarios. Noticeably, none of our 'scenarios' exhibit decreasing regional inequalities. Our opinion is that, at least in the first half of our projection horizon, regional inequalities will continue to grow, and even if this tendency will sometimes reverse, we might assume that regional inequalities will not fall behind the average historical level (measured from 2000 to 2017). Regarding the upper limit of our projections, we might assume that regional concentration will not continue beyond all limits, therefore the increase of regional variation will first slow down, then stop, and may even decrease.

\subsection{Out-of-sample testing and accuracy measures}

We check the predictive capacity of our projection methods with out-of-sample tests using historical data. It is generally accepted that forecasting methods are best assessed for accuracy using out-of-sample tests rather than in-sample tests (goodness of fit to past data), since in-sample errors are likely to understate forecasting errors, and methods selected by best in-sample fit may not best predict post-sample data (Tashman [2000]). In this test, we split our historical time series into a 'learning' or 'training' period and a 'test' period. It is a general requirement to set the length of the test period according to the required longest-term projection (Tashman [2000]). Since we focus on long-run projections, we are unable to fulfil this criterion, which is a limitation of this study and must be considered when interpreting the results. Our historical database covers 18 years, therefore, we decided to split the time series to have a learning period 2000-2012, and a test period 2013-2017. This choice was affected by the nature of the GDP dynamics in this period, namely, the apparent impact of the global financial crisis. (See Figures 1 and 2.) Nevertheless, we can expect that similar fluctuations are likely in the horizon of our predictions, and our data suggests that the crisis had a hysteretic effect on the Hungarian economic development (Váry [2018]). Therefore, it seems reasonable to start the test period after the crisis, while retaining a sufficiently long learning period. 
Figure 1. GDP at constant prices with Hodrick-Prescott filtered trend lines

Million HUF

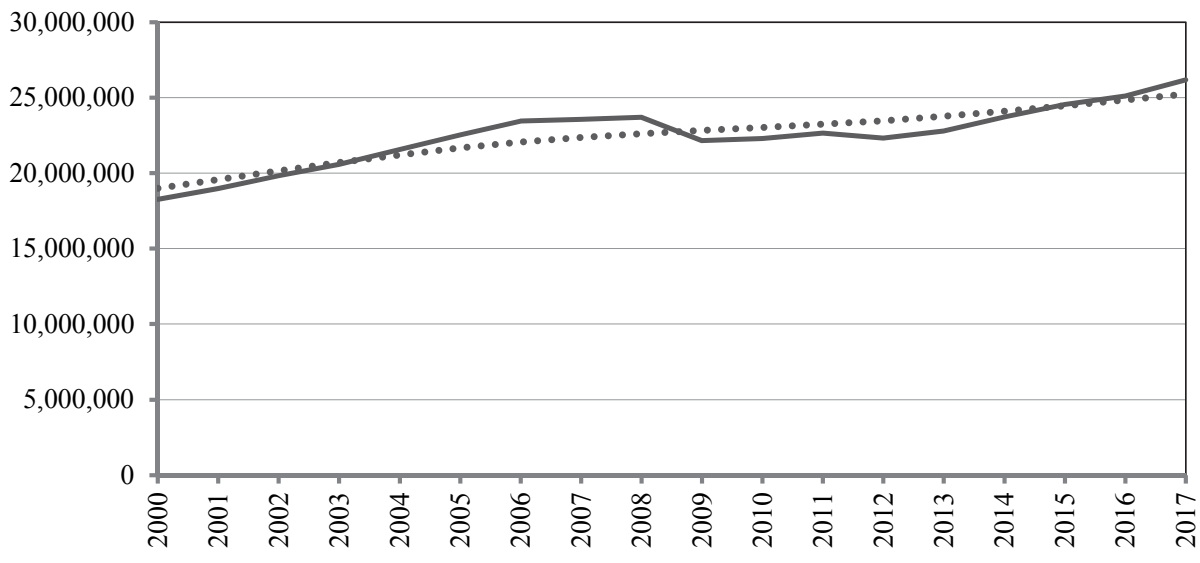

GDP $\quad \cdots \cdots \cdot$ GDP HP

Note. Here and in the following figure, HP: Hodrick-Prescott filter.

Source: Own elaboration based on HCSO and NBH data.

Figure 2. Cross-sectional variance with Hodrick-Prescott filtered trend lines

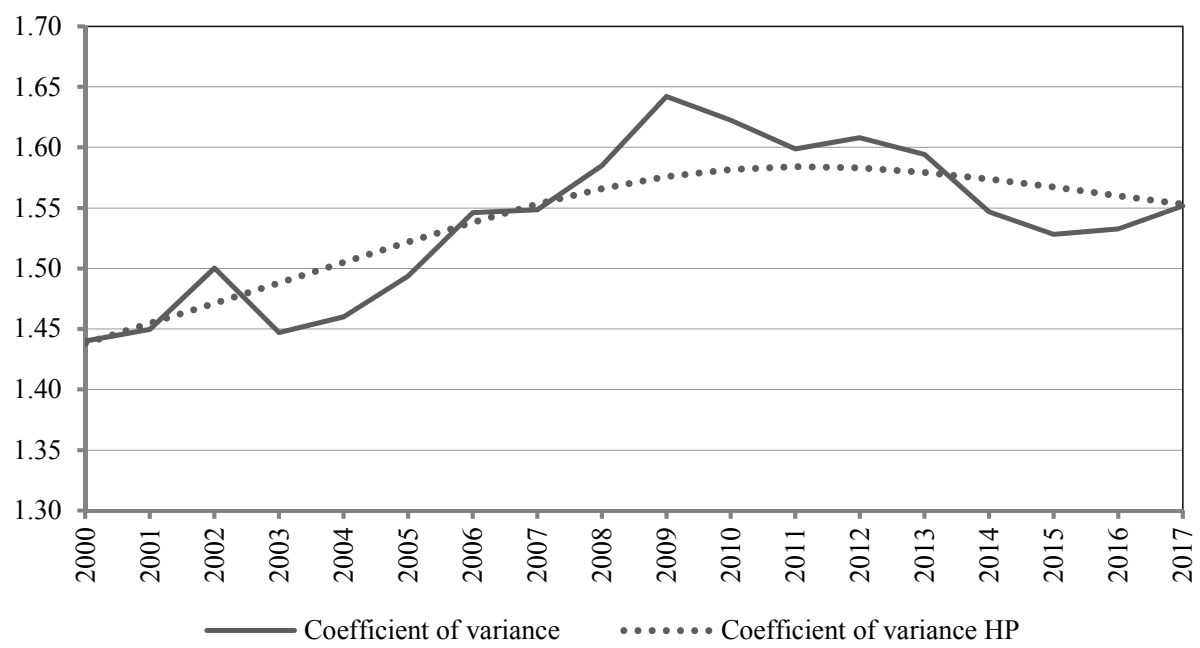

Note. Coefficient of variance: cross-sectional standard deviation divided by the mean GDP. Source: Own elaboration based on HCSO and NBH data.

We used standard statistical loss functions to check the predictive capacity of the projection methods. We need to establish three sets of decisions in connection with measuring predictive capacity. The first is the definition of the prediction error.

HungaRian STATISTICAL REVIEW, Volume 2, NuMBER 2, PP. 51-78. DOI: 10.35618/hsr2019.02.en051 
There are two obvious alternatives (see Green-Tashman [2008a]): on one hand, the prediction error can be measured as the difference between the actual and predicted values of a given variable. This formulation accommodates statistical convention and the practice of statistical software packages; furthermore, it is intuitive when assessing performance against a budget or plan, because a positive value indicates that a budget has been exceeded or a plan has been surpassed. On the other hand, prediction error defined as the forecasted value minus the actual value reflects the intuition that a positive error represents an over-forecast and a negative error an under-forecast, and it is more consistent with the concepts of bias. In this study, we prefer this latter solution.

The second decision concerns the selection of the appropriate accuracy measure, preferably more than one. When reporting error statistics, we compare results of the measures that use either absolute deviations or relative (percentage) errors. In the first class of accuracy measures, the mean absolute error, MSE (mean squared error), and RMSE (root mean squared error) are often used. With respect to the nature of our data, we encounter the problem of comparability between regions when using these measures, since they cannot account for the scale of the given territorial unit, i.e. the same prediction error counts more in a smaller county and less in a bigger county. For this reason, we prefer using relative accuracy measures, specifically, MAPE (mean absolute percentage error) and AMAPE (adjusted [or symmetric] mean absolute percentage error). While in absolute numbers, the largest prediction error is measured in Budapest, in relative terms, the percentage error is the smallest there among the counties. MAPE seems to be a reasonable choice, however, it has certain shortcomings (Makridakis [1993]), notably that it is not a symmetric measure: equal errors above the actual value result in a greater absolute percentage error than those below the actual value. For this reason, we take the adjusted MAPE as decisive when studying prediction errors.

Third, in connection with the first two decisions, we have to choose the appropriate denominator for MAPE: would it be the actual or the predicted value? Green-Tashman [2008b] argue that using the actual value provides a more intuitive interpretation. This argument is in line with our aims; therefore, we follow this practice. In sum, we test the predictive capacity of our projections with the following statistical loss functions:

$$
\begin{gathered}
R M S E=\sqrt{\frac{\sum\left(\hat{Y}_{t+m}-Y_{t+m}\right)^{2}}{m},} \\
M A P E=\frac{100}{m} \sum \frac{\left|\hat{Y}_{t+m}-Y_{t+m}\right|}{\left|Y_{t+m}\right|},
\end{gathered}
$$




$$
A M A P E=\frac{100}{m} \sum \frac{\left|\hat{Y}_{t+m}-Y_{t+m}\right|}{\left|\hat{Y}_{t+m}+Y_{t+m}\right|},
$$

where $t$ is the year of the last historical data taken as known (the year 2012), $m$, running from 1 to 5 (between 2013 and 2017) is the number of years in the test period, and the variable with a hat denotes the predicted value of the given variable in period $t+m .^{3}$

Unfortunately, none of these measures informs us about whether the inaccuracy occurs in the form of over- or under-forecast.

\section{Results}

The results will be presented in two sub-sections. First, the long-term GDP trends are calculated according to three basic projection variants, and then the accuracy is tested on a historical data set. During this, several further possible variants are taken into account.

\subsection{Predicting long-term GDP trends at the NUTS 3 level}

In the process of our long-term projections, we take the data of the year 2018 as the starting point $(n=1)$. Based on the presented national-level projections and the regional-level economic indicators, the following regionalised results are achieved.

As expected, GDP values predicted according to Variant 3 fall between those of Variant 1 and 2 in most cases, and Variant 2 and 3 produce equal results at the beginning of the projection horizon. (See Tables 3 and 4.) This is generally reflected by the time series of the cross-sectional coefficient of variance. For the economically most dynamic regions, Variant 2 assures the highest predicted GDP values, while for the most backward ones, Variant 1 is the most 'favourable' in most cases. Due to its outstanding relative economic weight, Budapest is the NUTS 3 region that is most accurately represented by the national average.

${ }^{3}$ We have computed all these error measures, but due to page limitation, we present only AMAPE here.

Hungarian Statistical ReVIEW, VOlume 2, NumBer 2, PP. 51-78. DOI: 10.35618/hsr2019.02.en051 
Table 4

GDP values at the NUTS 3 level in 2015 and projections in percentage of the 2015 value

\begin{tabular}{|c|c|c|c|c|c|c|c|c|c|c|}
\hline \multirow{2}{*}{$\begin{array}{l}\text { NUTS } 3 \\
\text { region/Country }\end{array}$} & \multirow{2}{*}{$\begin{array}{c}2015^{*} \\
\text { (million } \\
\text { HUF) }\end{array}$} & \multicolumn{3}{|c|}{ Variant 1} & \multicolumn{3}{|c|}{ Variant 2} & \multicolumn{3}{|c|}{ Variant 3} \\
\hline & & 2020 & 2040 & 2060 & 2020 & 2040 & 2060 & 2020 & 2040 & 2060 \\
\hline Budapest & $8,917,983$ & 104.8 & 150.3 & 191.2 & 107.2 & 155.1 & 194.7 & 107.2 & 155.0 & 197.2 \\
\hline Pest & $2,532,863$ & 101.2 & 145.1 & 184.5 & 112.7 & 211.9 & 345.6 & 112.7 & 193.9 & 249.2 \\
\hline Fejér & $1,073,232$ & 97.8 & 140.3 & 178.4 & 96.0 & 122.5 & 135.4 & 96.0 & 127.8 & 161.8 \\
\hline $\begin{array}{l}\text { Komárom- } \\
\text { Esztergom }\end{array}$ & 762,490 & 104.1 & 149.3 & 189.9 & 105.0 & 183.8 & 279.0 & 105.0 & 172.1 & 220.6 \\
\hline Veszprém & 633,595 & 107.8 & 154.6 & 196.7 & 102.4 & 112.5 & 107.2 & 102.4 & 123.5 & 155.3 \\
\hline $\begin{array}{l}\text { Györ-Moson- } \\
\text { Sopron }\end{array}$ & $1,485,422$ & 91.5 & 131.2 & 166.9 & 97.2 & 158.0 & 222.5 & 97.2 & 151.8 & 194.0 \\
\hline Vas & 612,623 & 103.1 & 147.8 & 188.0 & 96.7 & 118.2 & 125.3 & 96.7 & 125.1 & 158.0 \\
\hline Zala & 552,951 & 109.9 & 157.6 & 200.4 & 101.2 & 119.5 & 122.2 & 101.2 & 127.9 & 161.4 \\
\hline Baranya & 583,911 & 117.8 & 168.9 & 214.8 & 113.2 & 128.0 & 125.4 & 113.2 & 139.1 & 175.2 \\
\hline Somogy & 471,820 & 112.3 & 161.1 & 204.9 & 104.6 & 125.0 & 129.4 & 104.6 & 133.3 & 168.2 \\
\hline Tolna & 410,210 & 107.6 & 154.4 & 196.3 & 97.4 & 110.0 & 107.8 & 97.4 & 119.6 & 150.6 \\
\hline $\begin{array}{l}\text { Borsod- } \\
\text { Abaúj- } \\
\text { Zemplén }\end{array}$ & $1,175,681$ & 99.3 & 142.4 & 181.1 & 103.2 & 150.5 & 190.2 & 103.2 & 150.0 & 190.8 \\
\hline Heves & 532,635 & 105.6 & 151.5 & 192.7 & 102.8 & 137.6 & 159.8 & 102.8 & 141.2 & 179.0 \\
\hline Nógrád & 210,188 & 121.0 & 173.5 & 220.6 & 114.3 & 112.7 & 96.4 & 114.3 & 128.4 & 160.9 \\
\hline Hajdú-Bihar & 962,633 & 106.2 & 152.3 & 193.6 & 111.7 & 151.3 & 177.7 & 111.7 & 154.7 & 196.2 \\
\hline $\begin{array}{l}\text { Jász- } \\
\text { Nagykun- } \\
\text { Szolnok } \\
\end{array}$ & 602,732 & 108.9 & 156.2 & 198.6 & 104.3 & 132.9 & 146.8 & 104.3 & 138.7 & 175.5 \\
\hline $\begin{array}{l}\text { Szabolcs- } \\
\text { Szatmár- } \\
\text { Bereg }\end{array}$ & 781,418 & 104.6 & 150.0 & 190.8 & 118.6 & 151.6 & 168.0 & 118.6 & 158.3 & 200.4 \\
\hline Bács-Kiskun & 982,475 & 96.5 & 138.5 & 176.1 & 99.2 & 144.6 & 182.8 & 99.2 & 144.1 & 183.4 \\
\hline Békés & 517,072 & 110.8 & 158.9 & 202.1 & 105.8 & 109.5 & 98.3 & 105.8 & 122.7 & 154.0 \\
\hline Csongrád & 766,575 & 105.5 & 151.3 & 192.4 & 102.3 & 121.8 & 125.7 & 102.3 & 130.1 & 164.2 \\
\hline Hungary & $24,568,509$ & 105.7 & 151.6 & 192.8 & 105.7 & 151.6 & 192.8 & 105.7 & 151.6 & 192.8 \\
\hline
\end{tabular}

* At constant, 2005 prices.

Source: Own calculation based on HCSO and NBH data. 
Figure 3. Cross-sectional variance of projected NUTS-3-level GDP values

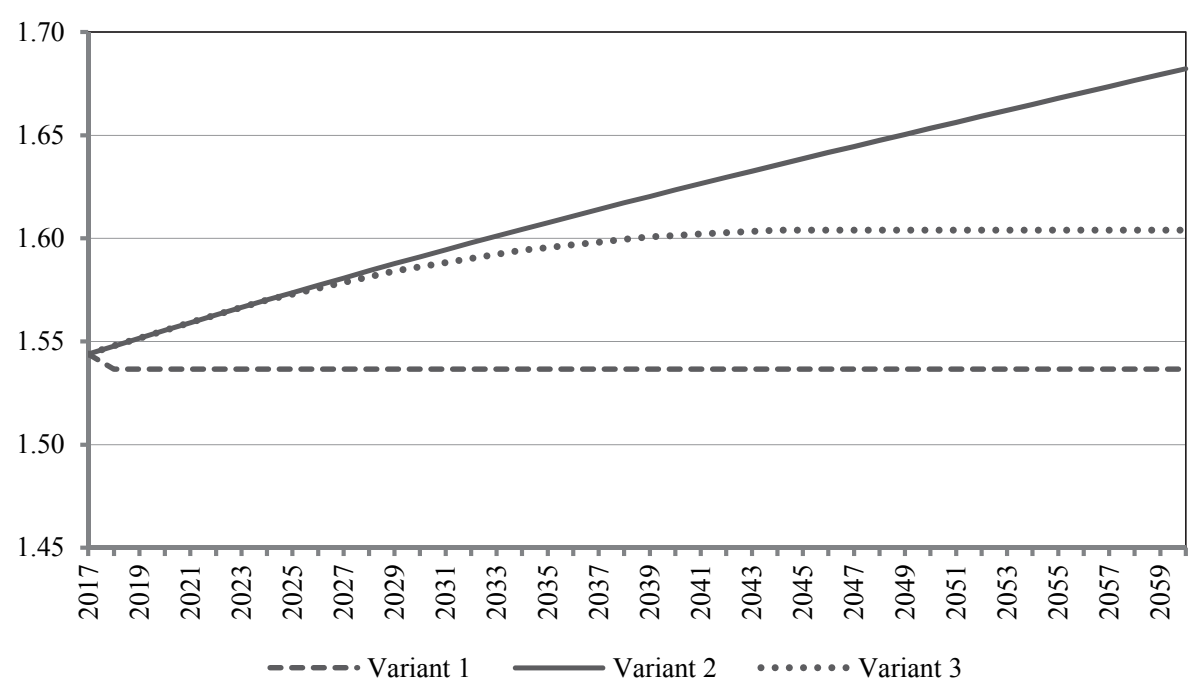

\subsection{Results of the out-of-sample tests}

In what follows, we shift our focus from the projected growth paths to the results of the out-of-sample tests, and experiment with the projection method under various weighting schemes. (See Table 3.) We have a significantly limited scope for experimenting with the weighting schemes that describe long-term convergence, since our historical time series covers only 18 years, within which the test period covers 5 years (while our projection period spans 43 years). Table 5 presents an example for the weighting scheme used in the out-of-sample tests, these national and regional weights are subject to our experiments.

Table 5

An example for the weighting scheme of the out-of-sample test

\begin{tabular}{l|c|c}
\hline \multicolumn{1}{c|}{ Year of the test period } & $w_{H U, t+m}$ & $w_{\text {reg, } t+m}$ \\
\hline 2013 & 0.80 & 0.20 \\
\hline 2014 & 0.85 & 0.15 \\
\hline 2015 & 0.90 & 0.10 \\
\hline 2016 & 0.95 & 0.05 \\
\hline 2017 & 1.00 & 0.00 \\
\hline
\end{tabular}


Of course, our aim cannot be to reach mechanically the best errors on the historical sample data, because our test period may not be fully representative of the Hungarian regional processes, but it may help to understand the mechanisms behind our extrapolation methods. In choosing the best weighting scheme for long-term projections, theoretical considerations should also drive our decision. Two important parameters determine the weighting scheme: the initial level of $w_{H U}\left(=w_{H U, 2013}\right)$ and a parameter describing the speed of convergence (which determines the period of full convergence ${ }^{4}$ ).

Table 6 presents the results of the out-of-sample error tests with respect to AMAPE for the three main variants and three other selected variants as examples. Variant ' 0.5 ' represents time-invariant weights with $w_{H U}=w_{\text {reg }}=0.5$. Variant ' 0.8 ' represents time-invariant weights with $w_{H U}=0.8$ and $w_{\text {reg }}=0.2$. Variant 'Convergence' represents time-varying weights where the initial weight, $w_{H U, 2013}=0.8$ and increases annually by 0.05 (like the example in Table 5). This implies that NUTS-3-level growth rates are assumed to converge towards the national-level growth rate until 2017 and $w_{H U, 2017}$ equals 1. We note that RMSE and

MAPE values (not included due to page limitation) indicate the same relations between the variants as AMAPE values in the case of the aggregate GDP series, although specific regional results may be different.

Table 6 indicates that regarding the overall GDP-projection, the last variant came up as best, even when we projected GDP on the basis of its aggregate time series (column 6) and when it was projected on the basis of the multiplication of its components (column 5). The numbers in the last two columns show that differences between the two prediction methods (with or without decomposition) are insignificant, and for most variants, lower errors resulted when we elaborated the predictions without the decomposition. Of course, the decomposition adds more uncertainty in the computations because it is computed as the multiplication of four different projected time series, but in this case, it caused only a slight deterioration in the results. The last variant (named 'Convergence') seems to be the best choice with regard to GDP and labour productivity. In the out-of-sample tests of the two demographic indicators, the average past regional growth rates obtained the lowest errors (Variant 2), while in the case of employment, the best prediction method was the one with time-invariant weights and $w_{H U}=0.8$. Surprisingly, Variant 1 that downscales national GDP to the regional level on the basis of the average historical shares of NUTS 3 regions within the national aggregate often produced the highest prediction errors. As expected, the most accurate projections are obtained in the case of population and the active population, followed by employment; while the highest errors occurred in the case of

${ }^{4}$ This indicates the equalization of regional growth rates but does not actually mean equal volumes.

HungaRian STATISTICAL REVIEW, Volume 2, NuMBER 2, PP. 51-78. DOI: 10.35618/hsr2019.02.en051 
productivity projections. Differences in the accuracy of the projections can be observed also among the regions. (See Table A2 in the Appendix.)

Table 6

AMAPE values for selected weighting parameters

\begin{tabular}{l|c|c|c|c|c|c}
\hline \multicolumn{1}{|c|}{ Prediction method } & Population & Productivity & $\begin{array}{c}\text { Active } \\
\text { population }\end{array}$ & Employment & $\begin{array}{c}\text { GDP with } \\
\text { decomposition }\end{array}$ & $\begin{array}{c}\text { GDP without } \\
\text { decomposition }\end{array}$ \\
\hline Variant 1 & 1.753 & 2.845 & 1.775 & 1.896 & 3.276 & 3.360 \\
\hline Variant 2 & $\mathbf{0 . 3 1 0}$ & 3.169 & $\mathbf{0 . 3 6 6}$ & 1.419 & 3.186 & 3.193 \\
\hline Variant 3 & 0.411 & 2.834 & 0.472 & 1.355 & 2.720 & 2.708 \\
\hline Variant '0.5' & 0.455 & 2.702 & 0.495 & 1.322 & 2.562 & 2.547 \\
\hline Variant '0.8' & 0.597 & 2.572 & 0.622 & $\mathbf{1 . 3 0 3}$ & 2.325 & 2.313 \\
\hline Variant 'Convergence' & 0.630 & $\mathbf{2 . 5 5 8}$ & 0.656 & 1.310 & $\mathbf{2 . 2 9 8}$ & $\mathbf{2 . 2 9 0}$ \\
\hline
\end{tabular}

Note. The best errors are highlighted with italic bold.

Certainly, there are many more possible variants beyond those highlighted here. First, we run our out-of-sample tests with time-invariant national weights $\left(w_{H U, t+m}=w_{H U, 2013}\right)$ and study the consequences of its different values from $w_{H U}=0$ to $w_{H U}=1$ with $5 \%$ intervals, and report our results with respect to AMAPE. The results are depicted in Figure 4.

Figure 4. Prediction error as a function of the weight of the projected national-level growth rate

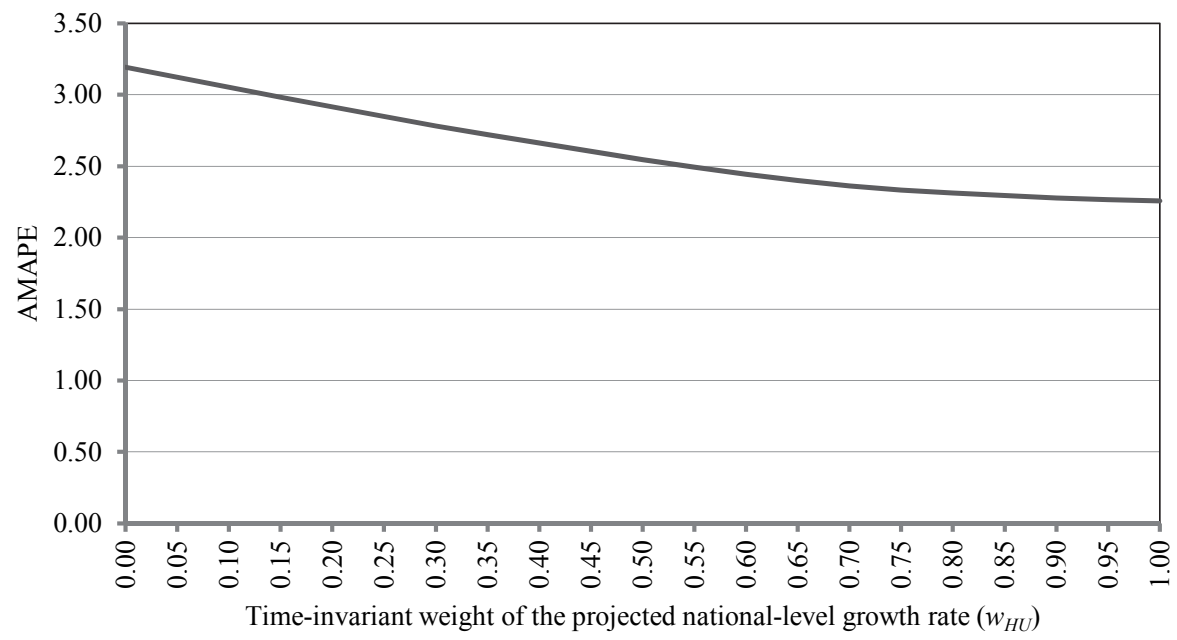

HungaRian STATISTICAL REVIEW, Volume 2, NuMBER 2, PP. 51-78. DOI: 10.35618/hsr2019.02.en051 
The results indicate that, in order to reach the minimum prediction error computed in the data of the period 2013-2017, the weight of the national-level projected growth rate should be set to $100 \%$, which implies that past regional-level growth rates should not have any importance in predicting GDP trends. This method is not fully equivalent to Variant 1, because, as explained in Sub-section 1.3., Variant 1 'freezes' regional inequalities at their average past level (measured between 2000 to 2012), while $w_{H U}=1$ 'freezes' cross-sectional variance at its 2012 level. In the test period, this method emerged as most effective for GDP predictions. As Figure 4 indicates, the prediction errors rapidly improve between $w_{H U}=0$ and $w_{H U}=0.5$, but above this value, the pace of improvement gradually decelerates. The lesson from these results is that national level development has a highly important role in explaining regional-level GDP processes. We checked for this statement with principal component analysis on the NUTS-3-level GDP time series in the period 2000-2017. (See Figure A1 and Table A1.) We could extract three principal components with eigenvalues higher than 1. Most Hungarian NUTS 3 regions have a relatively high component loading in the first component, and the average value of the loadings is 0.79. The most striking exceptions are Nógrád $(-0.086)$, Baranya (0.554), Békés $(0.601)$, and Zala counties $(0.600)$. These results suggest that the weight of the national-level growth rates is best set at $w_{H U}=0.8$ or at least $w_{H U} \geq 0.5$.

In order to see the numerical consequences of the selection of parameters, we depict the cross-sectional variance of the regional GDP values under different prediction methods (weighting schemes) in Figure 5 and contrast them with actual values.

Figure 5. Cross-sectional variance of NUTS-3-level GDP: actual

and out-of-sample predicted values according to the three main variants

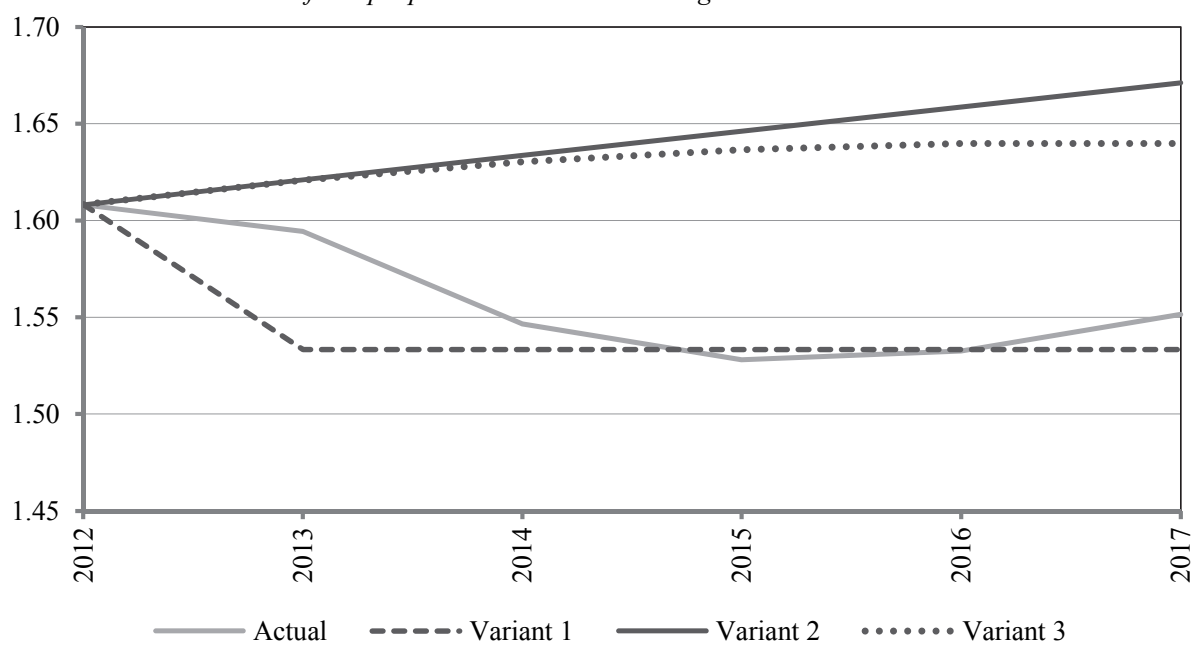

HungaRian STATISTICAL REVIEW, Volume 2, NuMBER 2, PP. 51-78. DOI: 10.35618/hsr2019.02.en051 
Our next experimentation moves beyond time-invariant weights, leaves them as special cases, and introduces a 'convergence parameter' that controls the speed of the convergence of regional-level weights from their initial level $\left(w_{H U, 2013}=1-w_{\text {reg, 2013 }}\right.$, which is also varying between 0 and 1 with $5 \%$ intervals as presented above) towards $w_{\text {reg }}=0$ (implying $w_{H U}=1$ ). This means that it is not necessary to run the weight of the national growth rate from $w_{H U, 2013}=0$ to $w_{H U, 2017}=1$, but several other options are available for analysis. On this basis, time-varying weights of the national-level growth rate are computed as follows:

$$
w_{H U, t+m+1}=w_{H U, t+m}+\gamma .
$$

This parameter runs from $\gamma=0.0000$ through $0.0100,0.0125,0.0250,0.0500$, $0.1000,0.1250$, and 0.2000 to 0.2500 . (In the example of Table $5, \gamma=0.0500$.) Its lowest value of 0.000 is equivalent to the time-invariant national weight scheme, and we set the upper limit so that $w_{H U} \leq 1$, because in the case of some $w_{H U, 2013}$ values that fall close to 1 , higher convergence parameters would result in a negative weight of past regional growth rates $\left(w_{\text {reg }}<0\right)$. We exclude this possibility in the computations, nevertheless, these cases would imply interregional convergence, however, the parameters' interpretation is not straightforward.

In accordance with the results presented in Figure 4 suggesting that $w_{H U}$ should be close to 1 , our test results prefer higher values of $\gamma$, i.e. faster convergence of past regional growth rates towards the national growth rate. (See Table 7.)

Our ultimate results combine the 21 different values of $w_{H U, 2013}$ and the nine different values of $\gamma$, which imply 189 different possible combinations of the weights. First, in the same manner as aforementioned, we provide the AMAPE values with respect to the GDP projections in two ways: both with and without the GDP decomposition described in Sub-section 1.2. Then, we individually scrutinize the results of the decomposed factors behind the GDP. The detailed numerical results are presented in Table 7 for the GDP prediction without the decomposition (and in Figure A7). Further results are indicated in Figures A2-A6. Our first observation is the same as mentioned above, namely, that there is no significant difference in the AMAPE values and their patterns between the decomposed projection and the projection of the aggregate GDP. This means that the decomposition followed by the growth accounting literature is not necessary at this stage of the research. The sophistication of these projection methods is thus recommended, and, at later stages, the decomposition must gain more importance.

Hungarian StatisticAl ReVIEW, Volume 2, NumBER 2, PP. 51-78. DOI: 10.35618/hsr2019.02.en051 
Detailed AMAPE results with varying parameters for the out-of-sample test of the GDP prediction without decomposition

\begin{tabular}{|c|c|c|c|c|c|c|c|c|c|}
\hline \multirow{2}{*}{$w_{H U, 2013}$} & \multicolumn{9}{|c|}{$\gamma$} \\
\hline & 0.0000 & 0.0100 & 0.0125 & 0.0250 & 0.0500 & 0.1000 & 0.1250 & 0.2000 & 0.2500 \\
\hline 0.00 & 3.193 & 3.173 & 3.168 & 3.143 & 3.093 & 2.994 & 2.945 & 2.799 & 2.708 \\
\hline 0.05 & 3.123 & 3.103 & 3.098 & 3.073 & 3.024 & 2.925 & 2.876 & 2.734 & 2.655 \\
\hline 0.10 & 3.053 & 3.034 & 3.029 & 3.004 & 2.955 & 2.857 & 2.808 & 2.672 & 2.607 \\
\hline 0.15 & 2.984 & 2.965 & 2.960 & 2.935 & 2.886 & 2.790 & 2.744 & 2.619 & 2.562 \\
\hline 0.20 & 2.917 & 2.897 & 2.892 & 2.868 & 2.819 & 2.726 & 2.683 & 2.569 & 2.518 \\
\hline 0.25 & 2.850 & 2.830 & 2.825 & 2.801 & 2.755 & 2.667 & 2.625 & 2.525 & 2.477 \\
\hline 0.30 & 2.783 & 2.765 & 2.760 & 2.738 & 2.694 & 2.609 & 2.572 & 2.482 & 2.442 \\
\hline 0.35 & 2.721 & 2.704 & 2.699 & 2.678 & 2.636 & 2.557 & 2.522 & 2.441 & 2.415 \\
\hline 0.40 & 2.663 & 2.646 & 2.642 & 2.620 & 2.578 & 2.507 & 2.475 & 2.409 & 2.389 \\
\hline 0.45 & 2.605 & 2.588 & 2.584 & 2.563 & 2.526 & 2.460 & 2.431 & 2.383 & 2.364 \\
\hline 0.50 & 2.547 & 2.532 & 2.528 & 2.510 & 2.476 & 2.416 & 2.393 & 2.358 & 2.341 \\
\hline 0.55 & 2.495 & 2.481 & 2.477 & 2.460 & 2.430 & 2.380 & 2.364 & 2.335 & 2.325 \\
\hline 0.60 & 2.446 & 2.433 & 2.430 & 2.415 & 2.388 & 2.351 & 2.338 & 2.316 & 2.310 \\
\hline 0.65 & 2.400 & 2.389 & 2.386 & 2.374 & 2.354 & 2.325 & 2.316 & 2.302 & 2.297 \\
\hline 0.70 & 2.362 & 2.353 & 2.351 & 2.343 & 2.328 & 2.305 & 2.300 & 2.291 & 2.286 \\
\hline 0.75 & 2.334 & 2.328 & 2.326 & 2.320 & 2.308 & 2.291 & 2.288 & 2.281 & 2.278 \\
\hline 0.80 & 2.313 & 2.308 & 2.307 & 2.301 & 2.290 & 2.281 & 2.279 & 2.273 & 2.273 \\
\hline 0.85 & 2.295 & 2.290 & 2.289 & 2.284 & 2.277 & 2.272 & 2.271 & 2.269 & 2.269 \\
\hline 0.90 & 2.278 & 2.275 & 2.274 & 2.271 & 2.268 & 2.265 & 2.265 & 2.265 & 2.265 \\
\hline 0.95 & 2.266 & 2.264 & 2.264 & 2.263 & 2.262 & 2.262 & 2.262 & 2.262 & 2.262 \\
\hline 1.00 & 2.259 & 2.259 & 2.259 & 2.259 & 2.259 & 2.259 & 2.259 & 2.259 & 2.259 \\
\hline
\end{tabular}

Note. The best error value is highlighted with italic bold.

With regard to population prediction, the best AMAPE values are produced by time-invariant weights $\left(w_{H U, t+m}=w_{H U, 2013}\right)$ where $w_{H U}=0.0$, i.e. only the past regional growth rates should count in predicting future regional population. (See Figure A2.) This result is the opposite as those for GDP prediction. In this case, AMAPE is 0.31 , implying a good accuracy.

In the case of productivity, the most accurate prediction can be delivered by timeinvariant weights where the weight of the national-level growth rate equals 1 , that is, only national-level developments should count (AMAPE is 2.54, see Figure A3). 
Concerning active population, the pattern is quite similar to the prediction of population, the lowest AMAPE (0.42) can be achieved with time-invariant weight $(\gamma=0.0)$ and the weight of the national-level growth rate $\left(w_{H U, t+m}\right)$ equalling 0.1 .

This means that past regional average growth rates should count with a 0.9 weight in predicting the future evolution of the active population at the regional level. (See Figure A4.)

Regarding the employed population aged between 15 and 64 years, the most accurate projection (AMAPE $=1.30$ ) was achieved with time-invariant weights $(\gamma=0.0)$ and the weight of the national-level growth rate equalling 0.7 , implying $w_{\text {reg }}=0.3$. (See Figure A5.)

For the overall GDP using the decomposition, $\gamma=0.0$ and $w_{H U}=1$ came up as the most accurate weighting scheme (AMAPE $=2.26$, see Figure A6). This means that although the test results are largely different for decomposed elements of the aggregate GDP, this fact does not have any impact on the prediction accuracy of the aggregate GDP after multiplying the decomposed predictions (see Equation /5/).

Finally, it would be useful to arrive at a recommendation for the selection of the parameters of the long-run regional-level GDP projection. In doing this, we use the test results of the five-year-long test period as well as intuition. Despite test results for the aggregate GDP projection, for the aforementioned considerations, we do not recommend discarding the use of past regional-level growth rates. We would prefer a combination of parameters with $w_{H U, t+1}=0.5$ and select the $\gamma$ parameter so that the full convergence occurs at the end of the projection horizon, in $2060(\gamma \approx 0.0111)$.

\section{Conclusions}

This paper studied certain simple, and therefore transparent, extrapolative projection methods regarding Hungarian NUTS-3-level GDP. Regional-level GDP values are linked to the national aggregate so that our projection method downscales an existing, external, national-level projection issued by the European Commission. We presented long-run projections until 2060 and tested their predictive capacity with out-of-sample tests on historical data. In searching for the best projection method, several decisions had to be made. Our results show that at this stage of the research, a simple projection of aggregate GDP time series gives comparable, if not better, results as the projection of decomposed GDP series. The out-of-sample tests elaborated on the period 2013-2017 show that the past interregional distribution of the GDP does not provide accurate input for predicting future regional GDP values,

Hungarian Statistical ReVIeW, Volume 2, NumBeR 2, PP. 51-78. DOI: 10.35618/hsr2019.02.en051 
and, even in the first part of the projection horizon, national-level GDP processes should count more in predicting regional-level trends compared with average historical regional-level trends. We argue that a combination of past regional-level growth rates and projected national-level growth rates should be used in downscaling national-level GDP values to the NUTS 3 level to achieve sufficiently accurate results in using the extrapolative method.

\section{Appendix}

Table A1

Component loadings of the first three principal components extracted from the Hungarian NUTS-3-level GDP time series, by NUTS 3 region

\begin{tabular}{l|c|c|c}
\hline \multirow{2}{*}{ NUTS 3 region } & \multicolumn{3}{|c}{ Component } \\
\cline { 2 - 4 } & 1 & 2 & 3 \\
\hline Budapest & 0.851 & -0.344 & -0.357 \\
\hline Pest & 0.873 & -0.189 & -0.424 \\
\hline Fejér & 0.889 & -0.173 & 0.368 \\
\hline Komárom-Esztergom & 0.865 & 0.162 & -0.420 \\
\hline Veszprém & 0.891 & 0.231 & 0.317 \\
\hline Györ-Moson-Sopron & 0.865 & -0.419 & 0.189 \\
\hline Vas & 0.822 & 0.017 & 0.434 \\
\hline Zala & 0.600 & 0.543 & -0.436 \\
\hline Baranya & 0.554 & 0.709 & -0.287 \\
\hline Somogy & 0.897 & 0.260 & -0.155 \\
\hline Tolna & 0.687 & -0.680 & 0.062 \\
\hline Borsod-Abaúj-Zemplén & 0.958 & 0.176 & 0.143 \\
\hline Heves & 0.951 & 0.167 & -0.037 \\
\hline Nógrád & -0.086 & 0.965 & 0.167 \\
\hline Hajdú-Bihar & 0.919 & -0.123 & -0.300 \\
\hline Jász-Nagykun-Szolnok & 0.926 & -0.019 & -0.023 \\
\hline Szabolcs-Szatmár-Bereg & 0.968 & -0.042 & 0.135 \\
\hline Bács-Kiskun & 0.927 & -0.278 & 0.206 \\
\hline Békés & 0.601 & 0.569 & 0.518 \\
\hline Csongrád & 0.973 & -0.027 & 0.001 \\
\hline & & & \\
\hline & & &
\end{tabular}


Figure A1. The first three principal components extracted from the Hungarian NUTS-3-level GDP time series, by year

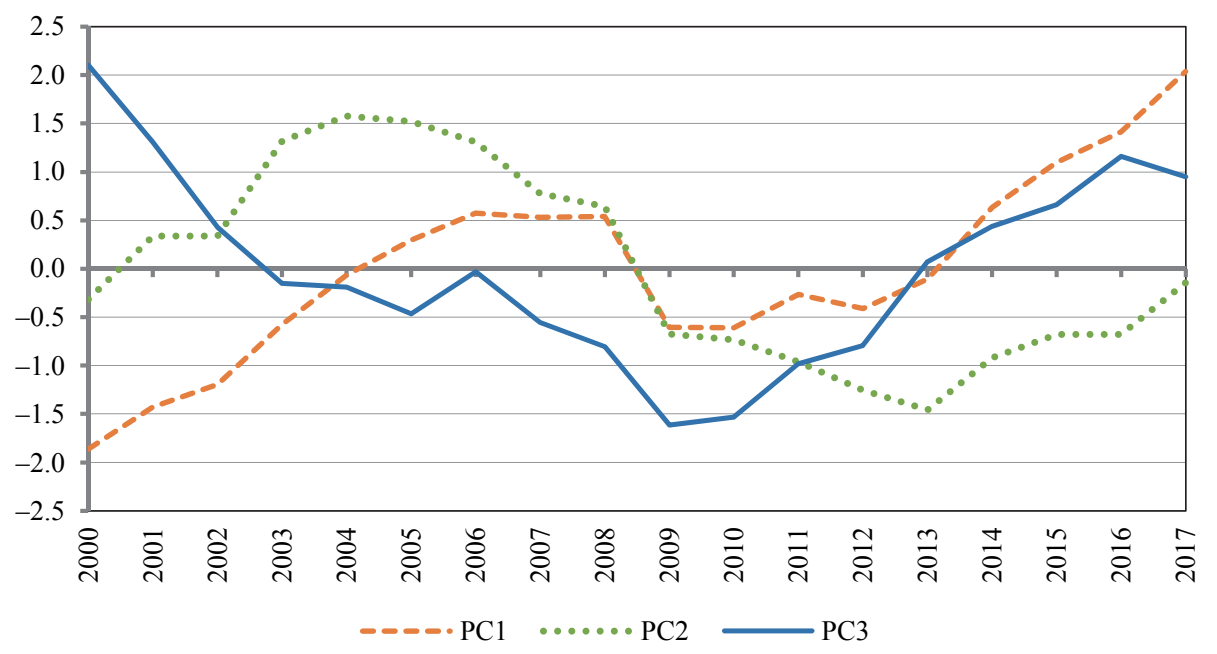

Note. PC: principal component.

Figure A2. AMAPE values in the out-of-sample test of population

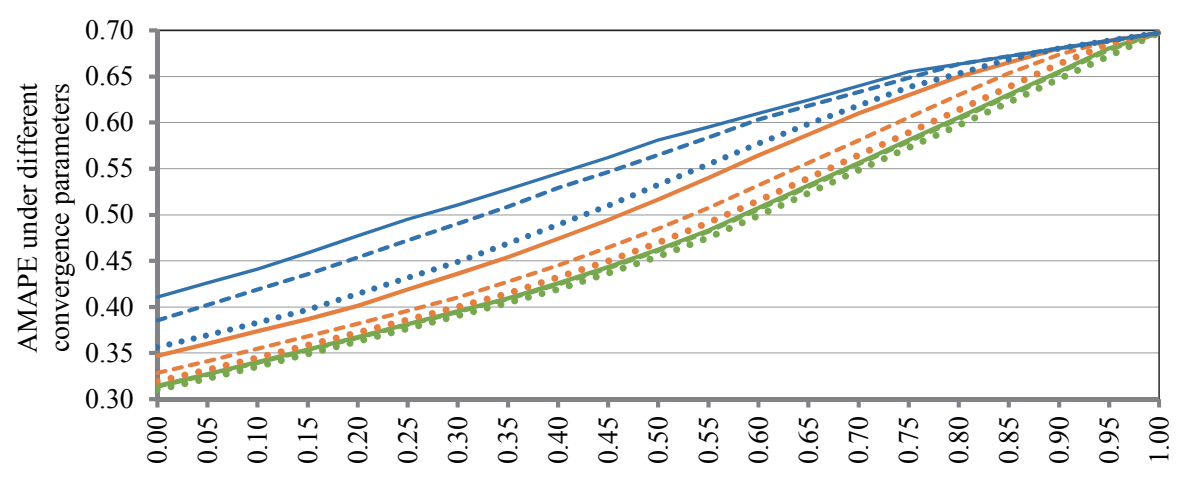

Weight of the national growth rate in 2013

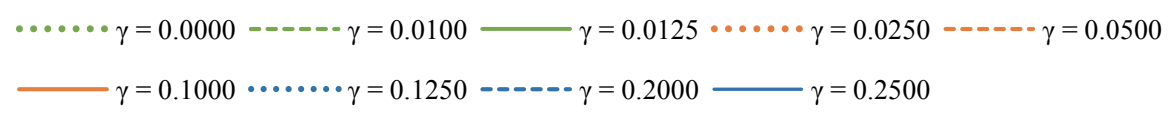



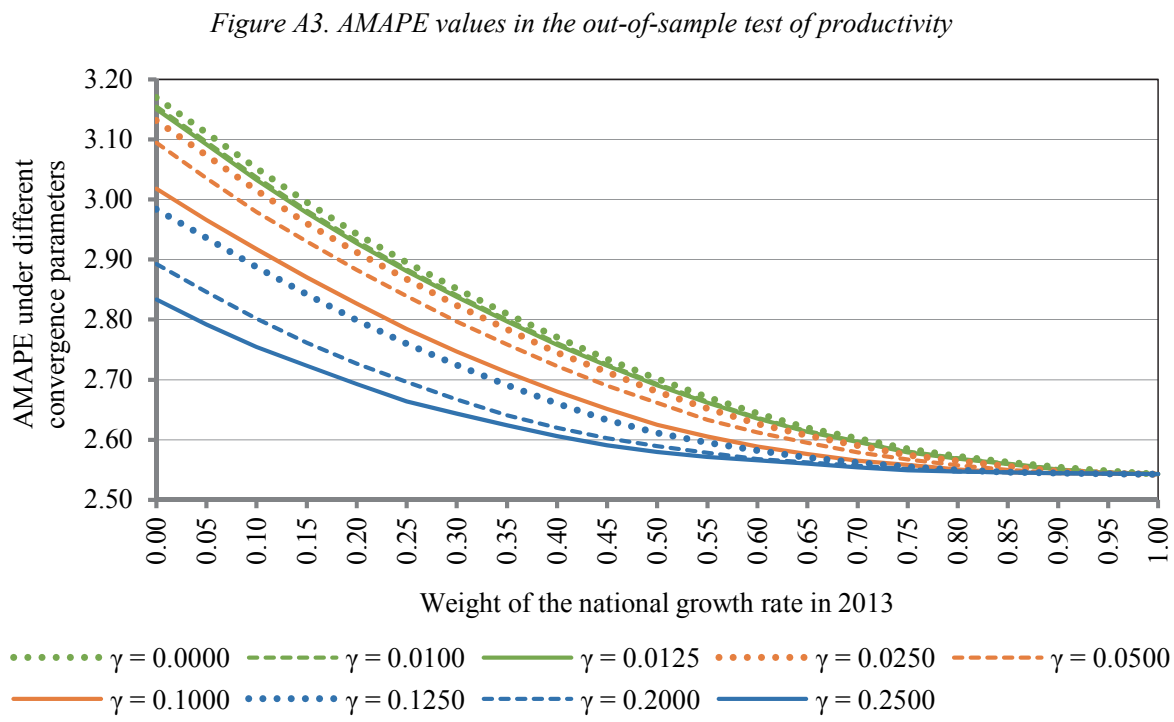

Figure A4. AMAPE values in the out-of-sample test of active population

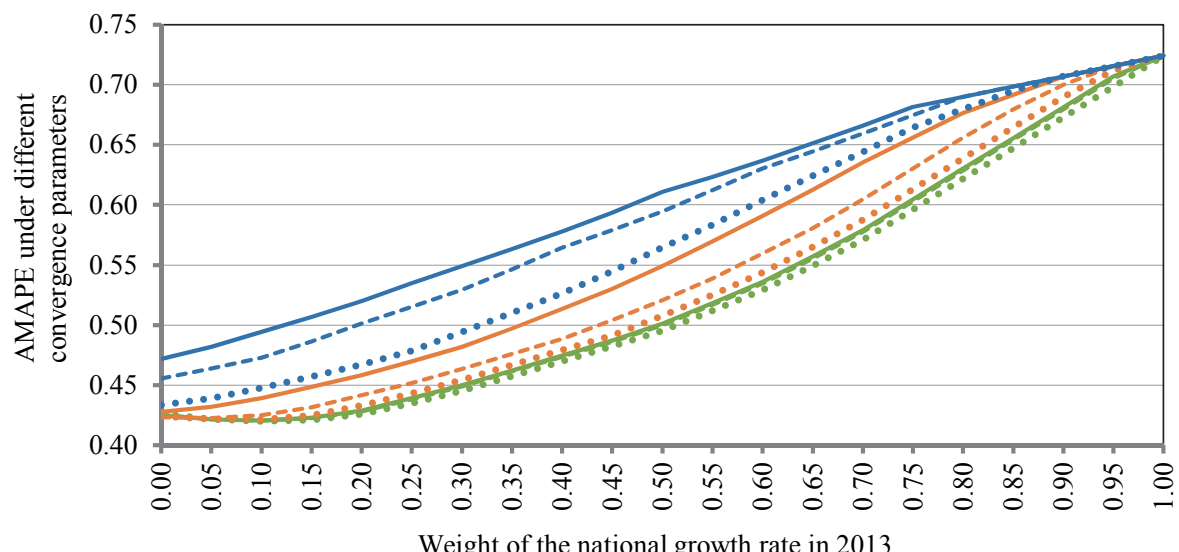

Weight of the national growth rate in 2013

$\begin{aligned} \cdots \cdots \gamma & =0.0000 \quad \cdots--\gamma \gamma=0.0100-\gamma=0.0125 \cdots \cdots \gamma \gamma=0.0250 \quad-----\gamma=0.0500 \\ \gamma & =0.1000 \cdots \cdots \gamma=0.1250 \quad \cdots---\gamma=0.2000 \longrightarrow \gamma=0.2500\end{aligned}$




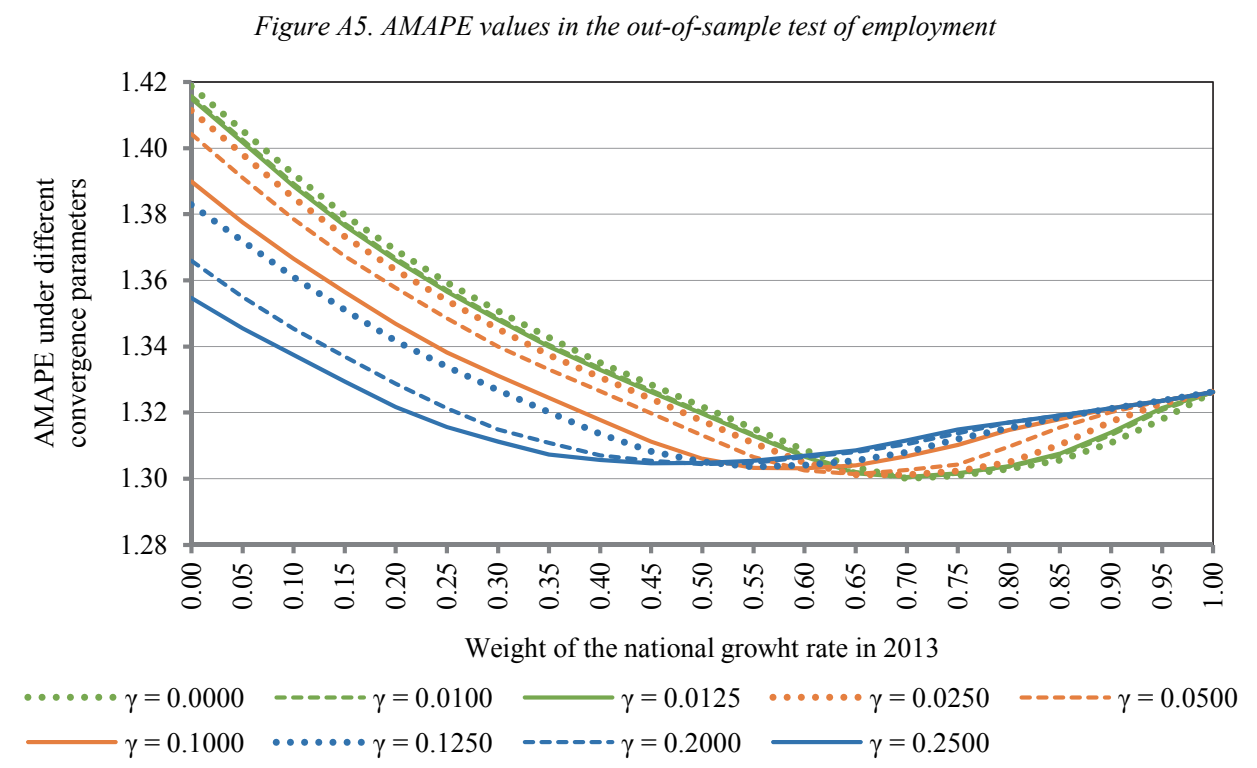

Figure A6. AMAPE values in the out-of-sample test of GDP with decomposition

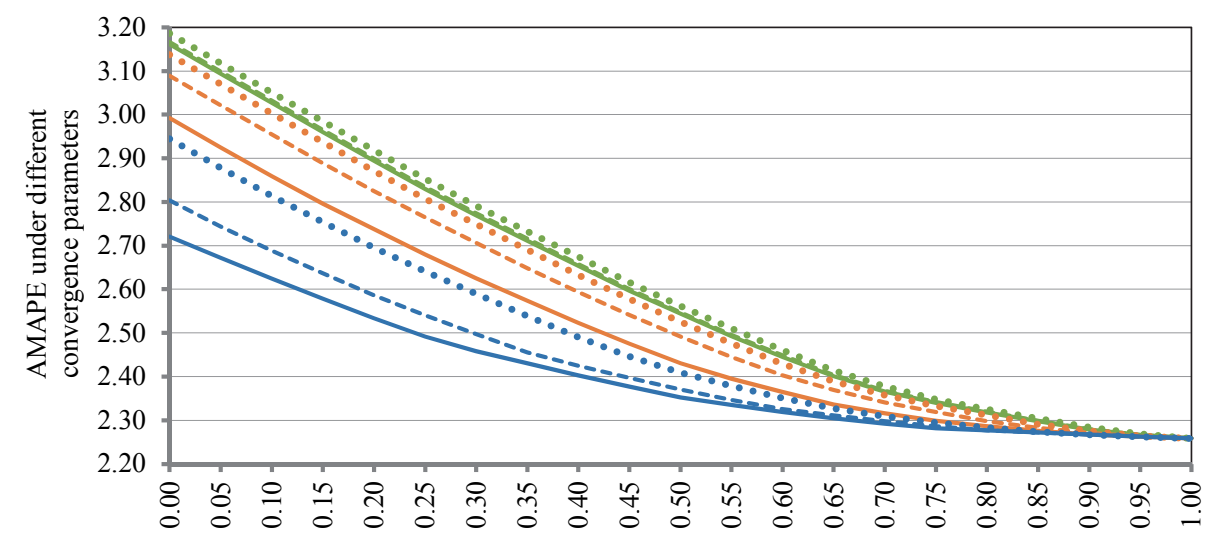

Weight of the national growth rate in 2013

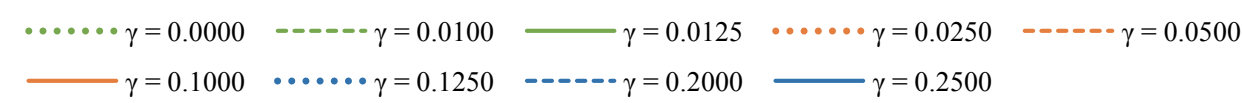




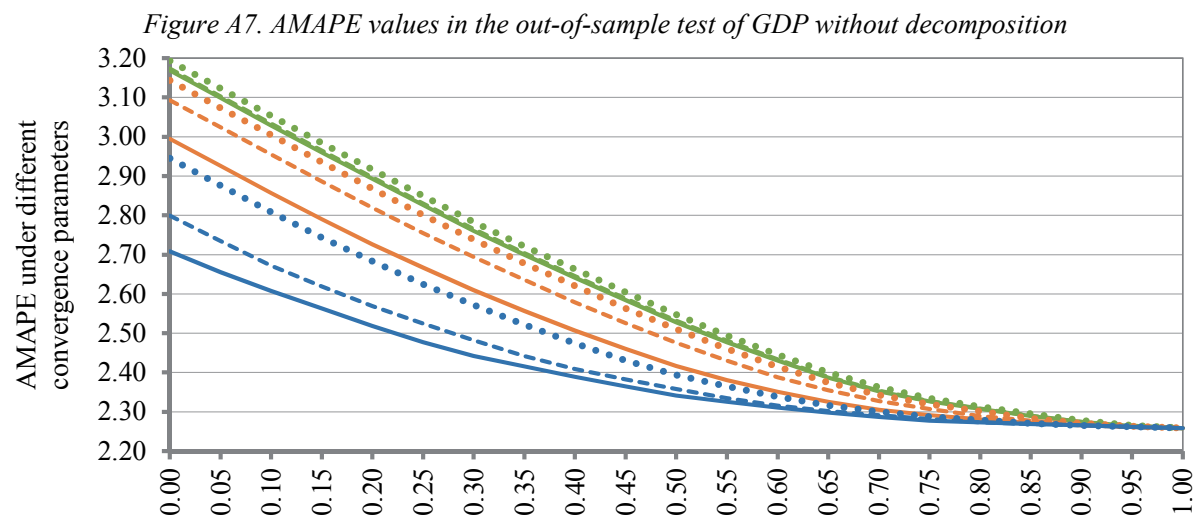

Weight of the national growth rate in 2013

$$
\begin{aligned}
& \cdots \cdots \gamma=0.0000-----\gamma=0.0100-\gamma=0.0125 \cdots \cdots \gamma=0.0250 \quad-----\gamma=0.0500 \\
& \gamma=0.1000 \cdots \cdots \gamma=0.1250 \quad \cdots \cdots--\gamma=0.2000-\gamma=0.2500
\end{aligned}
$$

Table A2

\begin{tabular}{|c|c|c|c|c|c|c|}
\hline NUTS 3 region & Population & $\begin{array}{c}\text { Labour } \\
\text { productivity }\end{array}$ & $\begin{array}{c}\text { Active } \\
\text { population }\end{array}$ & Employment & $\begin{array}{c}\text { GDP with } \\
\text { decomposition }\end{array}$ & $\begin{array}{l}\text { GDP without } \\
\text { decomposition }\end{array}$ \\
\hline Budapest & 1.13 & 2.70 & 0.98 & 0.56 & 1.99 & 1.99 \\
\hline Pest & 1.21 & 1.90 & 1.11 & 0.92 & 1.18 & 1.27 \\
\hline Fejér & 0.08 & 3.66 & 0.29 & 0.79 & 4.64 & 4.66 \\
\hline Komárom-Esztergom & 0.38 & 1.68 & 0.55 & 2.25 & 1.06 & 1.06 \\
\hline Veszprém & 0.56 & 0.76 & 0.79 & 0.83 & 2.50 & 2.53 \\
\hline Győr-Moson-Sopron & 1.18 & 5.09 & 1.17 & 0.60 & 6.77 & 6.79 \\
\hline Vas & 0.26 & 2.98 & 0.20 & 1.36 & 2.90 & 2.80 \\
\hline Zala & 0.64 & 4.29 & 0.90 & 2.27 & 5.26 & 5.21 \\
\hline Baranya & 0.90 & 5.45 & 1.09 & 2.49 & 2.13 & 2.13 \\
\hline Somogy & 0.61 & 1.88 & 0.69 & 1.30 & 1.60 & 1.63 \\
\hline Tolna & 0.76 & 3.11 & 0.96 & 1.95 & 2.26 & 2.21 \\
\hline Borsod-Abaúj-Zemplén & 1.04 & 1.50 & 0.61 & 2.42 & 4.28 & 4.27 \\
\hline Heves & 0.83 & 1.32 & 0.72 & 1.04 & 3.37 & 3.40 \\
\hline Nógrád & 1.14 & 3.75 & 0.93 & 2.61 & 2.83 & 2.96 \\
\hline Hajdú-Bihar & 0.24 & 4.50 & 0.28 & 0.90 & 2.39 & 2.39 \\
\hline Jász-Nagykun-Szolnok & 0.81 & 1.35 & 0.61 & 1.08 & 0.84 & 0.86 \\
\hline Szabolcs-Szatmár-Bereg & 0.26 & 2.17 & 0.93 & 1.80 & 1.40 & 1.39 \\
\hline Bács-Kiskun & 0.34 & 3.27 & 0.32 & 0.88 & 3.63 & 3.60 \\
\hline Békés & 1.14 & 2.29 & 1.04 & 1.56 & 2.40 & 2.41 \\
\hline Csongrád & 0.34 & 1.95 & 0.46 & 1.06 & 1.11 & 1.15 \\
\hline
\end{tabular}

Average AMAPE values by NUTS 3 regions and GDP components

Note. AMAPE averaged between the methods described in Table 6. 


\section{References}

BAlatoni, A. - MelláR, T. [2011]: Rövid távú előrejelzésre használt makroökonometriai modell Statisztikai Szemle. Vol. 89. No. 12. pp. 1213-1241.

BARANYAI, N. [2015]: Társadalmi-gazdasági folyamatok modellezése 1990 után. In: Czirfusz, M. Hoyk, E. - Suvák, A. (eds.): Klímaváltozás - Társadalom - Gazdaság. Hosszú távú területi folyamatok és trendek Magyarországon. Publikon Kiadó. Pécs. pp. 31-48.

Batista e Silva, F. - Dijkstra, L. - Martinez, P. V. - Lavalle, C. [2016]: Regionalisation of Demographic and Economic Projections. Trend and Convergence Scenarios from 2015 to 2060. JRC Science for Policy Report. https://www.doi.org/10.2788/458769

CzIrfusz, M. - HoyK, E. - SuvÁK, A. (eds.) [2015]: Klímaváltozás - Társadalom - Gazdaság. Hosszú távú területi folyamatok és trendek Magyarországon. Publikon Kiadó. Pécs.

DusEK, T. - KISS, J. P. [2008]: A regionális GDP értelmezésének és használatának problémái. Területi Statisztika. Vol. 48. No. 3. pp. 264-280.

EC (EuRopean COMmission) [2015]: The 2015 Ageing Report: Economic and Budgetary Projections for the 28 EU Member States (2013-2060). Publications Office of the European Union. Luxembourg. https://doi.org/10.2765/877631

Gaffin, S. R. - Rosenzweig, C. R. - Xing, X. - Yetman, G. [2004]: Downscaling and geo-spatial gridding of socio-economic projections from the IPCC Special Report on Emissions Scenarios (SRES). Global Environmental Change. Vol. 14 . Issue 2. pp. 105-123. https://doi.org/10.1016/j.gloenvcha.2004.02.004

GreEn, K. - TASHMAN, L. [2008a]: Forecast accuracy measurement: Should we define forecast error as $e=F-A$ or $e=A-F$ ? Foresight. Issue 10 . Summer. pp. 38-40. https://foresight.forecasters.org/product/foresight-issue-10

GREEN, K. - TASHMAN, L. [2008b]: Forecast accuracy measurement: percentage error metrics: what denominator? Foresight. Issue 12. Winter. pp. 27-31.

JАKOBI, Á. [2004] Kisérletek a hazai területi egyenlőtlenségek előrejelzésére. In: Nemes Nagy, J. (ed.): Térségi és települési növekedési pályák Magyarországon. Regionális Tudományi Tanulmányok 9. ELTE Regionális Földrajzi Tanszék-ELTE Regionális Tudományi Kutatócsoport. Budapest. pp. 107-124.

KeRESZTÉLy, T. [2004]: Eőrejelzés és szcenárióelemzés hosszú távú makromodellel. Statisztikai Szemle. Vol. 82. Nos. 10-11.pp. 919-944.

Kopoin, A. - Moran, K. - PARÉ, J. [2013] Forecasting regional GDP with factor models: How useful are national and international data? Economics Letters. Vol. 121. No. 2. pp. 267-270. https://doi.org/10.1016/j.econlet.2013.08.007

KoppÁnY, K. - KovÁcs, Z. - DuseK, T. [2019]: A gazdasági teljesítmény területi eloszlása és koncentrációja Magyarországon. In: Reisinger, A. - Kecskés, P. - Buics, L. - Berkes, J. Balassa, B. (eds.): Kulturális gazdaság. A Kautz Gyula Emlékkonferencia elektronikus formában megjelenő kötete. Széchenyi István Egyetem. Győr. pp. 1-12.

LENGyel, I. [2000]: A regionális versenyképességről. Közgazdasági Szemle. Vol. XLVII. December. pp. 962-987. 
LENGYel, I. - Kotosz, B. [2018]: Felzárkózás és/vagy távolságtartó követés? A visegrádi országok térségeinek fejlődéséröl. Tér és Társadalom. Vol. 32. No. 1. pp. 5-26. https://doi.org/10.17649/TET.32.1.2910

Lengyel, I. - VARGA, A. [2018]: A magyar gazdasági növekedés térbeli korlátai - helyzetkép és alapvető dilemmák. Közgazdasági Szemle. Vol. LXV. May. pp. 499-524. https://doi.org/ 10.18414/KSZ.2018.5.499

LuX, G. [2015]: A területi modellezés története Magyarországon 1945 és 1990 között. In: Czirfusz, M. - Hoyk, E. - Suvák, A. (eds.): Klímaváltozás - Társadalom - Gazdaság. Hosszú távú területi folyamatok és trendek Magyarországon. Publikon Kiadó. Pécs. pp. 13-30.

MAKRIDAKIS, S. [1993]: Accuracy measures: theoretical and practical concerns. International Journal of Forecasting. Vol. 9. Issue 4. pp. 527-529. https://doi.org/10.1016/01692070(93)90079-3

OECD (Organization for ECONOMic Co-operation And Development) [2019]: Long-term Baseline Projections. No. 103. OECD Economic Outlook: Statistics and Projections (database). https://doi.org/10.1787/68465614-en

RAPACH, D. E. - StRauSS, J. K. [2012]: Forecasting US state-level employment growth: an amalgamation approach. International Journal of Forecasting. Vol. 28. No. 2. pp. 315-327. https://doi.org/10.1016/j.ijforecast.2011.08.004

RAPPAI, G. [2014]: Rendszertelen idôsorok modellezése spline-interpolációval. Statisztikai Szemle. Vol. 92. Nos. 8-9. pp. 766-791.

Riahi, K. - van Vuuren, D. P. - Kriegler, E. - Edmonds, J. - O’Neill, B. C. - Fujimori, S. Bauer, N. - Calvin, K. - Dellink, R. - Fricko, O. - Lutz, W. - Popp, A. - Crespo Cuaresma, J. - Samir, K. C. - Leimbach, M. - Jiang, L. - Kram, T. - RaO, S. Emmerling, J. - Ebi, K. - Hasegawa, T. - Havlík, P. - Humpenöder, F. - Aleluia Da Silva, L. - Smith, S. - Stehfest, E. - Bosetti, V. - Eom, J. - GernaAt, D. - Masui, T. Rogelj, J. - Strefler, J. - Drouet, L. - Krey, V. - Luderer, G. - Harmsen, M. TAKahashi, K. - Baumstark, L. - Doelman, J. C. - Kainuma, M. - Klimont, Z. Marangoni, G. - Lotze-Campen, H. - Obersteiner, M. - TABeaU, A. - TAVoni, M. [2017]: The shared socioeconomic pathways and their energy, land use, and greenhouse gas emissions implications: an overview. Global Environmental Change. Vol. 42. January. pp. 153-168. http://dx.doi.org/10.1016/j.gloenvcha.2016.05.009

Royuela, V. - Veneri, P. - RAMOS, R. [2019]: The short-run relationship between inequality and growth: evidence from OECD regions during the Great Recession. Regional Studies. Vol. 53. No. 4. pp. 574-586. https://doi.org/10.1080/00343404.2018.1476752

SMAнó, M. [2007]: Kísérlet egy régió szimulációs modelljének kidolgozására. Tér és Társadalom. Vol. 21. No. 1. pp. 117-129. https://doi.org/10.17649/TET.21.1.1097

Stiglitz, J. E. - SEN, A. - Fitoussi, J. [2010]: A Bizottság jelentése a gazdasági teljesítmény és a társadalmi fejlődés méréséről. Statisztikai Szemle. Vol. 88. No. 3. pp. 305-320.

SzabÓ, P. [2015]: Régió és térszerkezet. Az elmélettöl a területpolitikáig. ELTE Eötvös Kiadó. Budapest.

TASHMAN, L. J. [2000]: Out-of-sample tests of forecasting accuracy: an analysis and review. International Journal of Forecasting. Vol. 16. Issue 4. pp. 437-450. https://doi.org/10.1016/S0169-2070(00)00065-0 
VARGA, A. [2018]: Földrajzi, makro- és regionális gazdasági hatáselemzés In: Faragó, L. (szerk.): Kortárs térelméletek kelet-közép-európai kontextusban. Dialóg Campus Kiadó. Budapest. pp. 123-139.

VÁRY, M. [2018]: A hiszterézis közgazdasági jelentőségéről posztkeynesi szemléletben Közgazdasági Szemle. Vol. LXV. October. pp. 1006-1047. https://doi.org/10.18414/ KSZ.2018.10.1006

ZsıBóK, Zs. [2018]: Linking macro and regional level economic forecasts: alternative regional growth paths in Hungary. Deturope. Vol. 10. No. 3. pp. 120-142. http://hdl.handle.net/11155/1848 